\title{
Moist and dry heating-induced changes in protein molecular structure, protein subfractions, and nutrient profiles in camelina seeds
}

\author{
Quanhui Peng, ${ }^{*} \dagger$ Nazir A. Khan, ${ }^{*}$ Zhisheng Wang, $\dagger$ and Peiqiang $\mathrm{Yu}^{*} \ddagger^{1}$ \\ *Department of Animal and Poultry Science, University of Saskatchewan, Saskatoon, SK, Canada, S7N 5A8 \\ †Animal Nutrition Institute, Sichuan Agriculture University, Sichuan 625014, China \\ $\ddagger$ Department of Animal Science, Tianjin Agricultural University, Tianjin 300384, China
}

\begin{abstract}
The objectives of the present study were to investigate the nutritive value of camelina seeds (Camelina sativa L. Crantz) in ruminant nutrition and to use molecular spectroscopy as a novel technique to quantify the heat-induced changes in protein molecular structures in relation to protein digestive behavior in the rumen and intestine of dairy cattle. In this study, camelina seeds were used as a model for feed protein. The seeds were kept as raw (control) or heated in an autoclave (moist heating) or in an air-draft oven (dry heating) at $120^{\circ} \mathrm{C}$ for $60 \mathrm{~min}$. The parameters evaluated were (1) chemical profiles, (2) Cornell Net Protein and Carbohydrate System protein subfractions, (3) nutrient digestibilities and estimated energy values, (4) in situ rumen degradation and intestinal digestibility, and (5) protein molecular structures. Compared with raw seeds, moist heating markedly decreased (52.73 to $20.41 \%$ ) the content of soluble protein and increased (2.00 to 9.01\%) the content of neutral detergent insoluble protein in total crude protein (CP). Subsequently, the rapidly degradable Cornell Net Protein and Carbohydrate System CP fraction markedly decreased (45.06 to $16.69 \% \mathrm{CP}$ ), with a concomitant increase in the intermediately degradable (45.28 to $74.02 \% \mathrm{CP})$ and slowly degradable (1.13 to $8.02 \% \mathrm{CP}$ ) fractions, demonstrating a decrease in overall protein degradability in the rumen. The in situ rumen incubation study revealed that moist heating decreased ( 75.45 to $57.92 \%$ ) rumen-degradable protein and increased (43.90 to $82.95 \%$ ) intestinal digestibility of rumen-undegradable protein. The molecular spectroscopy study revealed that moist heating increased the amide I-to-amide II ratio and decreased $\alpha$-helix and $\alpha$-helix-to- $\beta$-sheet ratio. In contrast, dry heating did not significantly change CP solubility, rumen degradability, intestinal digestibility, and protein molecular structures compared with the raw seeds. Our results
\end{abstract}

Received July 25, 2013.

Accepted September 22, 2013.

${ }^{1}$ Corresponding author: Peiqiang.yu@usask.ca indicated that, compared with dry heating, moist heating markedly changed protein chemical profiles, protein subfractions, rumen protein degradability, and intestinal digestibility, which were associated with changes in protein molecular structures (amide I-to-amid II ratio and $\alpha$-helix-to- $\beta$-sheet ratio). Moist heating improved the nutritive value and utilization of protein in camelina seeds compared with dry heating.

Key words: heat processing method, protein molecular structure, nutrient availability, camelina seed

\section{INTRODUCTION}

Camelina (Camelina sativa L. Crantz), also known as false flax or gold-of-pleasure, is an unexploited ancient oilseed crop in the family Brassicaceae. Recently, the crop has received increasing attention, primarily due to the use of its seeds as a source of high-quality oil and animal feed (Putnam et al., 1993; Kirkhus et al., 2013). As a result, the cultivated area of camelina is estimated to reach 0.607 million hectare in North America by 2013. Camelina seeds contain over $40 \%$ oil, and the oil is exceptionally high in $\mathrm{n}-3(>37 \%)$ and total polyunsaturated (>50\%) FA (Peiretti et al., 2007; Kirkhus et al., 2013), making it an attractive alternative source of n-3 FA to flaxseed (Moloney et al., 2012). The beneficial effects of camelina meal/cake or oil inclusion in animal diets on milk yield and composition of dairy cattle and ewes (Halmemies-Beauchet-Filleau et al., 2011; Szumacher-Strabel et al., 2011), circulating PUFA in beef cattle (Cappellozza et al., 2012), and the insulin sensitivity of dairy cattle during late pregnancy (Salin et al., 2012) have been intensively investigated. During the early and mid-lactation period, high-producing dairy cattle experience a state of negative energy balance due to lower DMI and high nutritional demands for milk production. One of the effective resolutions to improve energy balance is feeding of energy-dense, fat-supplemented rations. However, feeding $>5 \%$ of (unprotected) fat or oil negatively affects cellulolytic microflora in the rumen (Henderson, 1973) and DMI of dairy cows (Ruegsegger and Schultz, 1985). Alterna- 
tively, feeding of intact oilseeds directly to the animal can minimize the negative effects on rumen function. The positive effects of supplementing camelina seeds directly to animal diets have been reported in rabbits (Peiretti et al., 2007) and lambs (Noci et al., 2011; Moloney et al., 2012). However, to our knowledge, the nutritive value of camelina seeds for dairy cattle has not been evaluated.

Heat treatments have been widely used to decrease protein degradation in the rumen and optimize protein utilization in ruminants (Faldet et al., 1992; Chouinard et al., 1997; Wright et al., 2005). Heat processing alters the protein digestive behavior by changing the inherent molecular structure of protein $(\mathrm{Yu}, 2007)$, and recent investigations have shown that quantifying the heatinduced changes in the molecular structure of the whole protein is vital to determine optimal heating conditions and understand the changes in protein nutritional quality, digestive behavior, and utilization in animals (Doiron et al., 2009; Samadi and Yu, 2011). However, studies on the heat-induced changes in protein intrinsic molecular structures in relation to protein nutritive value and digestive behavior are extremely rare, partly due to the lack of appropriate analytical techniques. Conventional wet chemical analysis rely heavily on harsh chemicals for extraction and derivatization, which can destroy the native structure of protein, and fail to detect protein molecular structure or chemical makeup (Budevska, 2002). Recent research has shown that Fourier transform/infrared-attenuated total reflectance (FT/IR-ATR) molecular spectroscopy can be used as a rapid, direct, nondestructive, and noninvasive bioanalytical technique to detect protein molecular structures in the intact feed tissues (Yu, 2007; Doiron et al., 2009; Samadi and Yu, 2011).

Therefore, the present study was designed to use FT/ IR-ATR-based molecular spectroscopy to reveal protein molecular structures and characterize the nutritive value of whole camelina seeds in ruminant nutrition. The second objective was to correlate dry and moist heat-induced changes in protein molecular structures to the changes in protein nutritional value, and digestive behavior in the rumen and intestine of the dairy cattle. The parameters evaluated were (1) chemical profiles, (2) protein subfraction profiles, (3) nutrient digestibilities and estimated energy values, (4) in situ rumen degradation and intestinal digestibility, and (5) protein molecular structures in terms of amide I and amide II areas, $\alpha$-helices and $\beta$-sheets, as well as their ratio. We hypothesized that different heat processing methods would result in different changes in protein inherent molecular structure and that these changes are associated with protein digestive behaviors and availability in dairy cattle.

\section{MATERIALS AND METHODS}

\section{Heat Treatment and Processing}

Seeds from 2 camelina varieties (Blaine Creek and Celine), harvested in 2 different years (2010 and 2011) were obtained from Feeds Innovation Institute, University of Saskatchewan (Saskatoon, SK, Canada). For heat processing, a 1-kg sample of each camelina variety was spread in aluminum pans $(33 \times 23 \mathrm{~cm}$ and $5 \mathrm{~cm}$ high), and moist heated by autoclave (Amsco Eagle SG-3031; Steris Corp., Mentor, OH) at $1.05 \mathrm{~kg} / \mathrm{cm}^{2}$ pressure or dry heated (roasted) by air-draft oven for $60 \mathrm{~min}$ at $120^{\circ} \mathrm{C}$. The heat processing was carried out in a single batch and harvest years were used as replicate. The heated samples were subsequently cooled at room temperature $\left(20-22^{\circ} \mathrm{C}\right)$ for $30 \mathrm{~min}$ and stored at $4^{\circ} \mathrm{C}$ for further processing. Raw seeds were used as the control.

The seeds were ground through $0.25-\mathrm{mm}$ screen (Retsch ZM-1; Brinkmann Instruments Ltd., Mississauga, ON, Canada) for molecular spectral analysis. For chemical analysis, the seeds were ground through a 1-mm screen, whereas for in situ incubation, the seeds were ground through a 2-mm screen. During grinding, the samples were kept cool and slowly fed to the grinder to minimize sticking and clumping and to ensure that the seeds were cracked and not extruded.

\section{Molecular Spectroscopy}

The molecular spectroscopic analyses were performed at the molecular spectroscopy laboratory of the department of Animal and Poultry Science, University of Saskatchewan. The molecular spectral profiles were collected using a JASCO FT/IR-ATR-4200 spectrometer (Jasco Inc., Easton, MD). The FT/IR spectrometer was equipped with a ceramic IR light source and a deuterated L-alanine doped triglycine sulfate detector, and a MIRacle ATR accessory module and a ZnSe crystal and pressure clamp (Pike Technologies, Madison, WI). The spectra were generated in the mid-IR (ca. 4,000-800 $\mathrm{cm}^{-1}$; Figure 1) and fingerprint (ca. $1,800-800 \mathrm{~cm}^{-1}$; Figure 2) regions, with 128 co-added scans and a spectral resolution of $4 \mathrm{~cm}^{-1}$, in transmission mode. Each sample was run 5 times. The spectra were collected with Jasco Spectra Manager II software (Jasco Inc.) and corrected against air as the background. The molecular structural features of protein from the FT/IR spectra were quantified by OMNIC 7.3 software (Spectra-Tech Inc., Madison, WI). The spectral bands associated with protein functional groups were identified and assigned using information reported by Theodoridou and $\mathrm{Yu}$ (2013b). Briefly, the primary molecular structure of protein was characterized through the unique func- 
tional groups $(\mathrm{C}=\mathrm{O}, \mathrm{C}-\mathrm{N}$, and $\mathrm{N}-\mathrm{H})$ of peptide bonds in the amide $\mathrm{I}(\sim 80 \% \mathrm{C}=\mathrm{O}$ and $\sim 20 \% \mathrm{C}-\mathrm{N}$ stretching vibration; centered at a wavelength of ca. 1,655 $\left.\mathrm{cm}^{-1}\right)$ and amide II $(\sim 60 \% \mathrm{~N}-\mathrm{H}$ bending vibration, $\sim 40 \%$ $\mathrm{C}-\mathrm{N}$ stretching vibration; centered at ca. $1,550 \mathrm{~cm}^{-1}$ ) regions, which were detected as 2 absorption peaks within the wavelength region from ca. 1,720 to 1,485 $\mathrm{cm}^{-1}$. The secondary protein structure was characterized from the absorption peak heights of $\alpha$-helix (ca. $1,653 \mathrm{~cm}^{-1}$ ) and $\beta$-sheets (ca. $1,630 \mathrm{~cm}^{-1}$ ), which were detected in the amide I area using the second-derivative function of OMNIC 7.2 software (Figure 3 and 4). Ratios of the spectral intensities of amide I and amide II, and $\alpha$-helix and $\beta$-sheet were calculated using the absorbance intensity values.

\section{In Situ Rumen Incubation}

Four nonlactating Holstein dairy cattle, fitted with flexible rumen cannula (10-cm internal diameter; Bar Diamond Inc., Parma, ID) were used for the in situ incubation experiments. The animals were handled according to the recommendations of the Canadian Council on Animal Care (CCAC, 1993). The cows were individually fed a balanced TMR (15 kg/head per day on a DM basis). The ration was formulated according to NRC requirements for dry dairy cattle (NRC, 2001).
The detailed information on the diets is reported by Zhang and $\mathrm{Yu}$ (2012). The cows were fed twice daily in equal portions at 0800 and $1600 \mathrm{~h}$ and had $24 \mathrm{~h} / \mathrm{d}$ access to fresh drinking water. The standard method of rumen incubation as described by $\mathrm{Yu}$ et al. (2003) was used to determine the rumen degradation characteristics. Briefly, $7 \mathrm{~g}$ of coarsely (2-mm) ground sample of each treatment was weighed into preweighed and coded nylon bags $(10 \times 20 \mathrm{~cm})$ with a pore size of $41 \mu \mathrm{m}$ (Nitex 03-41/31 monofilament open mesh fabric; Screentec Corp., Mississauga, ON, Canada). The bags were tied $2 \mathrm{~cm}$ below the top, allowing a ratio of sample size to bag surface area of $19 \mathrm{mg} / \mathrm{cm}^{2}$. A polyester mesh bag $(45 \times 45 \mathrm{~cm})$, which was fixed to the cannula with a $90-\mathrm{cm}$-long rope, was used to place the sample bags in the rumen. A $250-\mathrm{mL}$ plastic bottle filled with gravel was also placed in the polyester mesh bag to dip the samples in rumen liquid. The bags were randomly incubated in the rumens of the 4 Holstein cows in 2 runs. The years of harvest were used as a run effect. To obtain enough residues for chemical analysis, 4 bags per treatment were incubated during each run, and the maximum number of bags in the rumen was 28 . After $16 \mathrm{~h}$ of incubation, the bags were removed from the rumen and rinsed 5 times with cold tap water to stop microbial enzymatic degradation and remove the adhering ruminal contents. Subsequently, the bags were

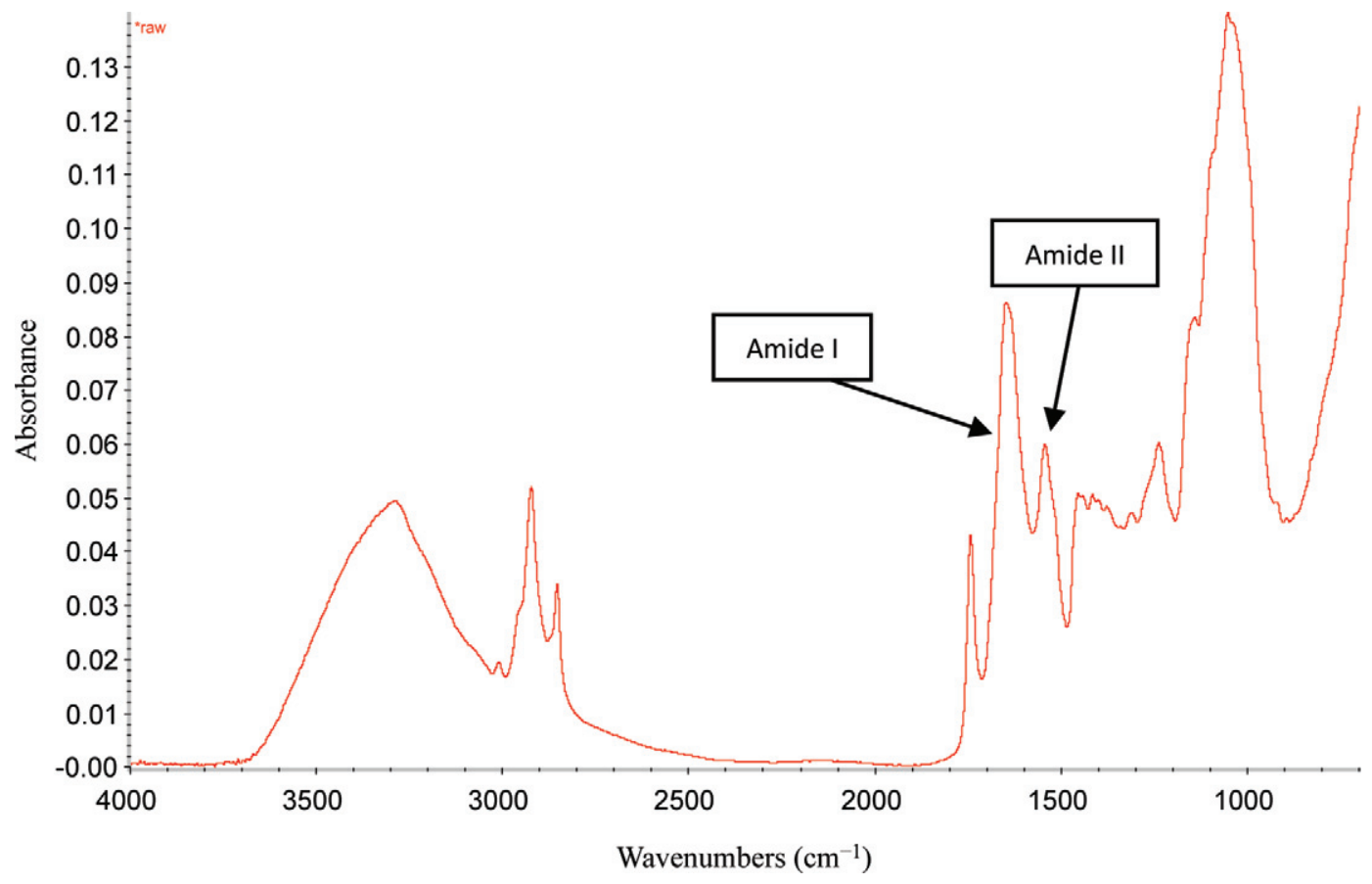

Figure 1. Typical Fourier transform infrared attenuated total reflectance (FT/IR-ATR; JASCO Inc., Easton, MD) biomolecular spectrum of camelina in the region ca. 4,000 to $800 \mathrm{~cm}^{-1}$, showing the chemical functional makeup of protein amide I and II. Color version available in the online PDF. 


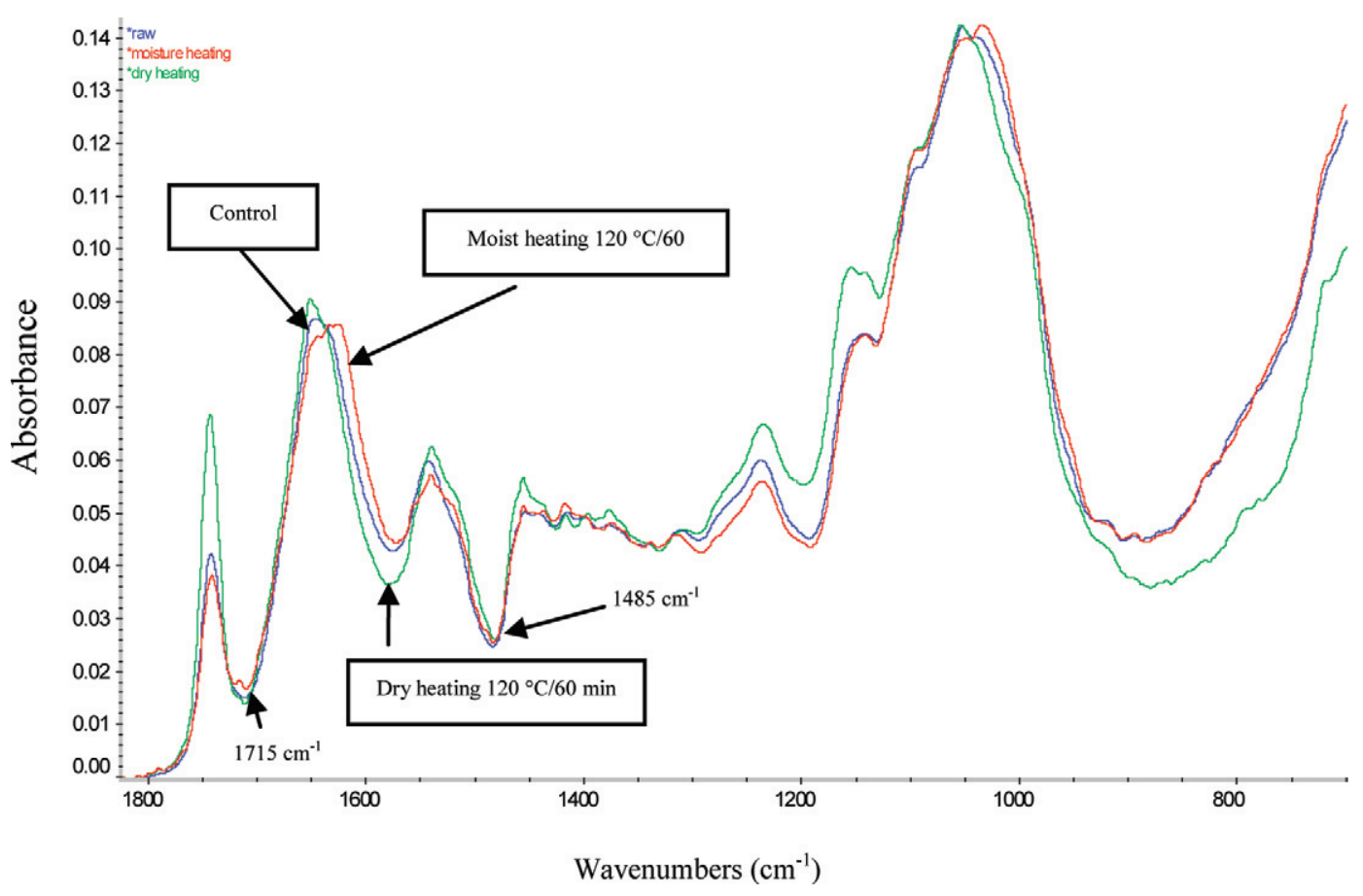

Figure 2. Typical Fourier transform/infrared-attenuated total reflectance (FT/IR-ATR; Jasco Inc., Easton, MD) biomolecular spectra of raw, dry-heated (oven heating at $120^{\circ} \mathrm{C}$ for $60 \mathrm{~min}$ ), and moist-heated (autoclaved heating at $120^{\circ} \mathrm{C}$ for 60 min) camelina seeds in the region ca. 1,715 to $1,485 \mathrm{~cm}^{-1}$. Color version available in the online PDF.

dried at $55^{\circ} \mathrm{C}$ for $48 \mathrm{~h}$ and reweighed. Residues were pooled together as per treatment. The dried samples were stored at $4^{\circ} \mathrm{C}$ for chemical analysis.

\section{Intestinal Protein Digestion Determination}

The intestinal digestibility of RUP was determined using the 3-step in vitro procedure as described by Calsamiglia and Stern (1995). Briefly, the dried residues of 16 -h rumen incubation, containing approximately 15 $\mathrm{mg}$ of $\mathrm{N}$, were transferred to $15-\mathrm{mL}$ centrifuge tubes. The residues were mixed with $10 \mathrm{~mL}$ of $0.1 \mathrm{~N} \mathrm{HCL}$ solution containing $1 \mathrm{~g}$ of pepsin/L. The mixtures were then incubated in a shaking water bath at $38^{\circ} \mathrm{C}$ for $1 \mathrm{~h}$. After incubation, the $\mathrm{pH}$ was neutralized by adding $0.5 \mathrm{~mL}$ of $1 \mathrm{~N} \mathrm{NaOH}$ and $13.5 \mathrm{~mL}$ of phosphate buffer (pH 7.8) containing $37.5 \mathrm{mg}$ of pancreatin, and incubated at $38^{\circ} \mathrm{C}$ for $24 \mathrm{~h}$. At the end of incubation, $3 \mathrm{~mL}$ of $100 \%$ (wt/ vol) TCA solution was immediately added to precipitate the undigested protein and stop enzymatic digestion. Samples were vortexed and centrifuged at 10,000 $\times g$ for $15 \mathrm{~min}$ at room temperature $\left(20-22^{\circ} \mathrm{C}\right)$. The supernatant was collected and analyzed for (soluble/digested) $\mathrm{N}$ content (AOAC, 1990; method 984.13).

\section{Chemical Characterization}

The ground (1-mm) samples of camelina seeds were analyzed for the contents of DM (method 930.15), ash (method 942.05), ether extract (EE; method 920.39), CP (method 984.13; using a Kjeltec 2400 autoanalyzer; Foss Analytical A/S, Hillerød, Denmark), ADF (method 973.18), and ADL (ADF method 973.18, followed by digestion with $72 \% \mathrm{H}_{2} \mathrm{SO}_{4}$ for $3 \mathrm{~h}$ ) according to the standard procedures of AOAC (1990). The NDF content was determined according to the procedure of Van Soest et al. (1991), without sodium sulfite but with heat-stable $\alpha$-amylase. The ADF and NDF values were expressed with the residual ash and corrected for $\mathrm{N}$, and the procedures were adapted for an ANKOM 200 Fiber Analyzer (Ankom Technology Corp., Fairport, $\mathrm{NY}$ ). Prior to ADF and NDF analysis, fat from the samples were extracted by 2 -h incubation in acetone to prevent the high fat content of camelina samples from giving inaccurately high values. The neutral detergentinsoluble CP (NDIP) and acid detergent-insoluble CP (ADIP) contents were determined according to the method of Licitra et al. (1996). The NPN content was determined by precipitating the true protein of the feed samples with tungstic acid and calculated as the difference between total $\mathrm{CP}$ content and $\mathrm{CP}$ content of the residues after filtration (Licitra et al., 1996). Soluble CP (SCP) was analyzed by incubating samples with borate-phosphate buffer for $1 \mathrm{~h}$ at $39^{\circ} \mathrm{C}$ and filtering the residues through Whatman \#54 filter paper (Roe et al. 1990). The SCP content was calculated as the difference between the total $\mathrm{CP}$ content and the $\mathrm{CP}$ 
A)

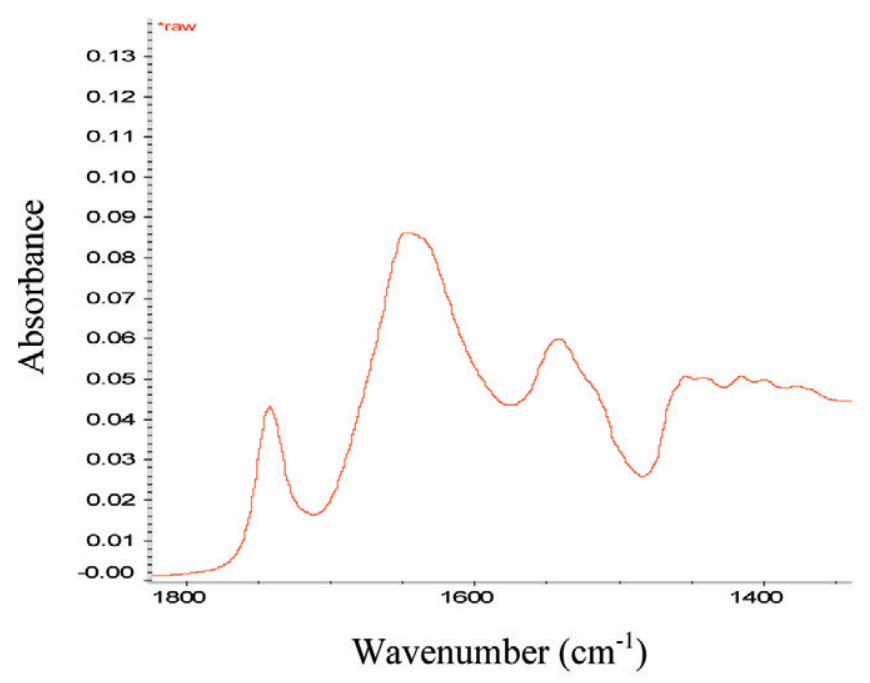

C)

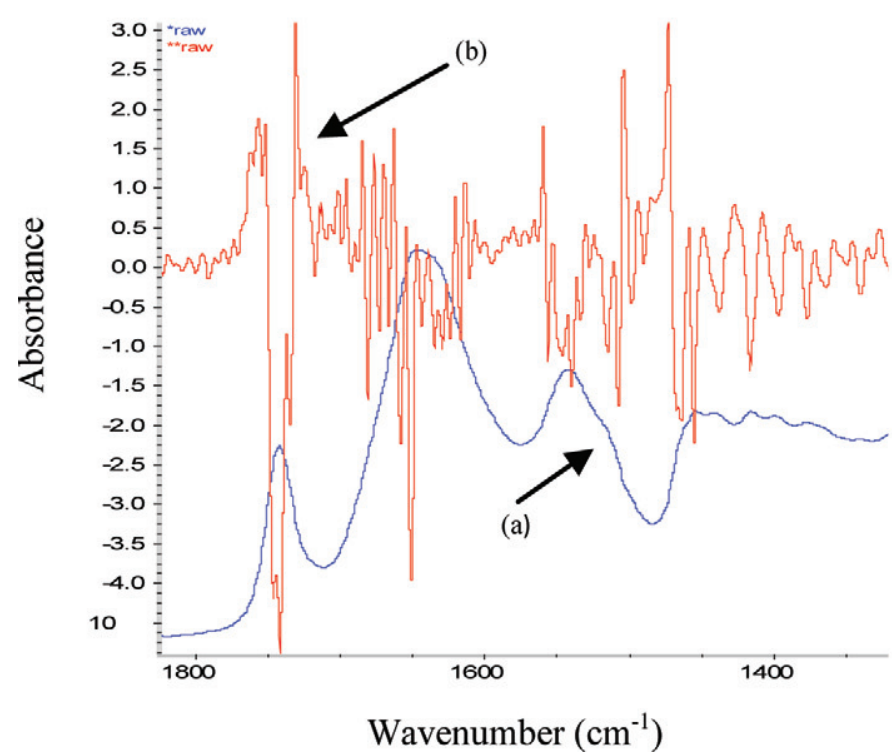

B)

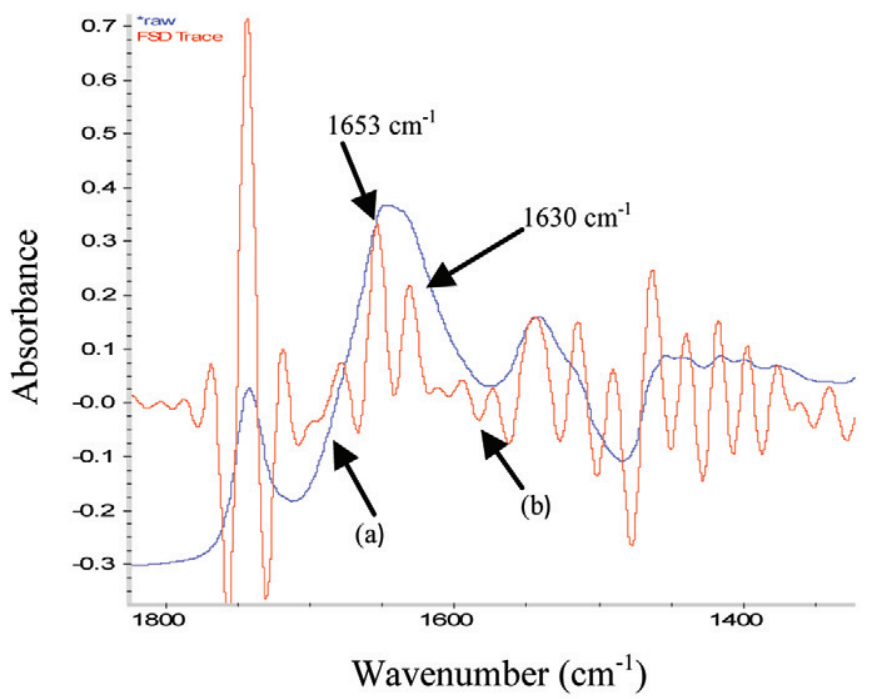

D)

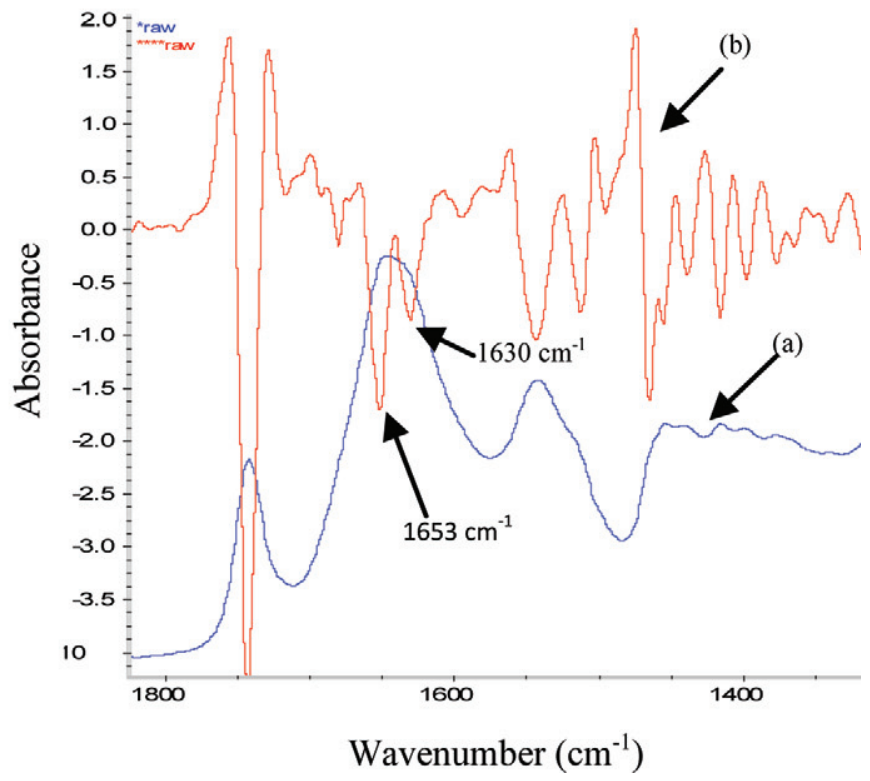

Figure 3. Typical Fourier transform/infrared-attenuated total reflectance (FT/IR-ATR; Jasco Inc., Easton, MD) biomolecular spectrum, the Fourier self-deconvolution (FSD) spectrum of camelina (raw, finely ground), showing both the FSD and the second-derivative spectra of $\alpha$-helix at ca. $1,653 \mathrm{~cm}^{-1}$ and $\beta$-sheet at ca. $1,630 \mathrm{~cm}^{-1}$. (A) Amide I and II region at ca. 1,715 to $1,485 \mathrm{~cm}^{-1}$; (B) spectra of amide I and II region (a = original spectrum; $b=$ FSD spectrum showing noise peaks; bandwidth $=96.5$; enhancement $=3.0)$; $(\mathrm{C})$ second-derivative spectra of the amide I and II region ( $\mathrm{a}=$ original spectrum; $\mathrm{b}=$ second-derivative spectrum showing noise peaks); (D) second-derivative spectra of the amide I and II region $(\mathrm{a}=$ original spectrum; $\mathrm{b}=$ spectrum after smoothing at a factor of 15$)$. Color version available in the online PDF.

content of residues. The NFC was calculated as NFC $=100-(\mathrm{NDF}-\mathrm{NDIP})-\mathrm{EE}-\mathrm{CP}-$ ash, and total carbohydrate $(\mathbf{C H O})$ content was calculated as $\mathrm{CHO}$ $=100-\mathrm{EE}-\mathrm{CP}-$ ash, according to NRC (2001).

\section{Fractionation of Protein}

The Cornell Net Carbohydrate and Protein System (CNCPS) was used to partition the CP content into
NPN (PA), true protein (PB), and unavailable protein (PC; Sniffen et al., 1992). The PB fraction was further fractionated into 3 subfractions (PB1, PB2, and PB3) that are believed to have different rates of degradation in the rumen. Fraction PB1 is soluble in borate-phosphate buffer and precipitated with TCA and calculated as SCP - PA. Fraction PB2 represents intermediately degradable protein and is calculated as $\mathrm{CP}-(\mathrm{PA}+$ $\mathrm{PB} 1+\mathrm{PB} 3+\mathrm{PC})$. Fraction PB3 is slowly degradable 


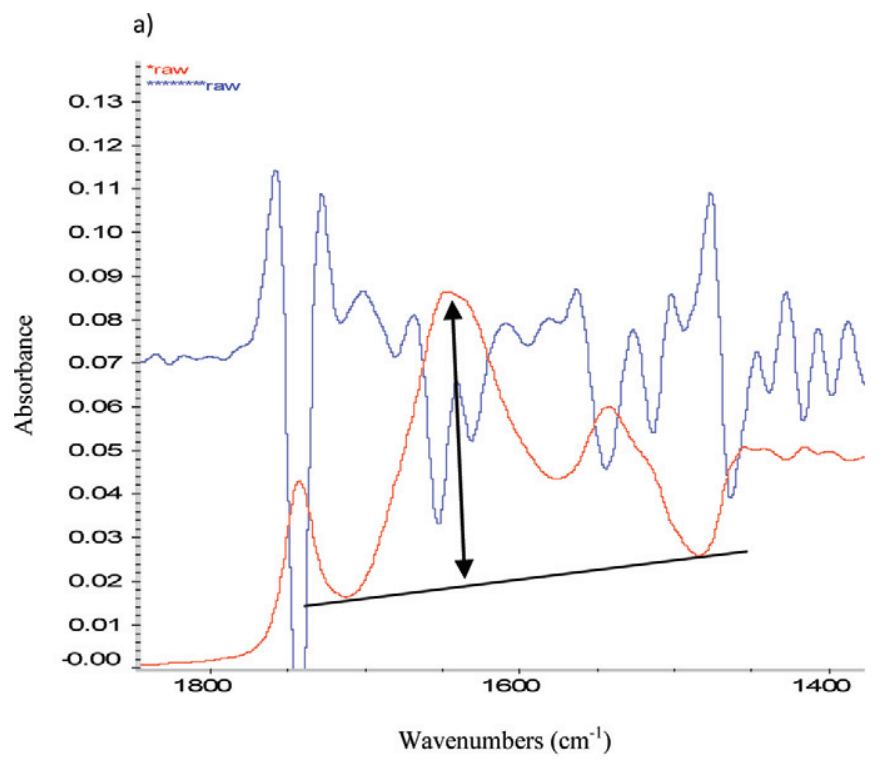

b)

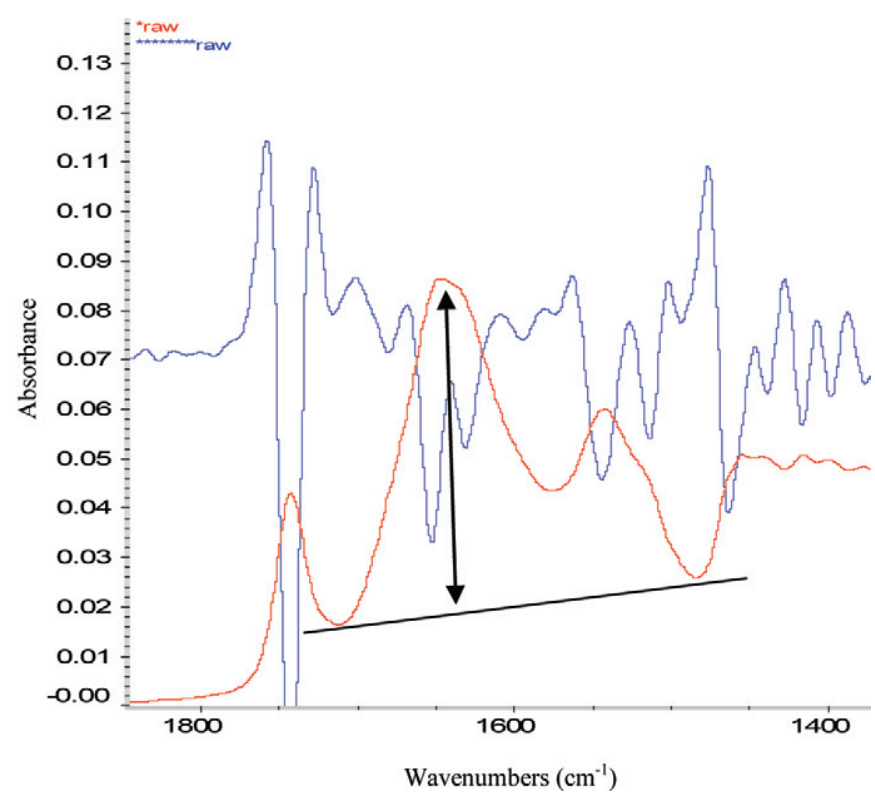

Figure 4. Typical Fourier transform/infrared-attenuated total reflectance (FT/IR-ATR; Jasco Inc., Easton, MD) biomolecular spectrum of raw camelina (finely ground): $\alpha$-helix peak center at ca. $1,653 \mathrm{~cm}^{-1}$ and $\beta$-sheet peak center at ca. $1,629 \mathrm{~cm}^{-1}$ and baseline: ca. $1,715-1,485 \mathrm{~cm}^{-1}$. The ratio of $\alpha$-helix to $\beta$-sheet was calculated by the peak height intensity ratio of ca. $1,653 \mathrm{~cm}^{-1}$ to ca. $1,630 \mathrm{~cm}^{-1}$. (a) Peak height of $\alpha$-helix (peak center: ca. $1,653 \mathrm{~cm}^{-1}$; baseline: ca. $1,715-1,485 \mathrm{~cm}^{-1}$ ); (b) peak height of $\beta$-sheet (peak center: ca. 1,629 $\mathrm{cm}^{-1}$; baseline: ca. $1,715-1,485 \mathrm{~cm}^{-1}$ ). Color version available in the online PDF.

$\mathrm{CP}$ and is calculated as NDIP - ADIP, and fraction $\mathrm{PC}$ is the ADIP. The relative degradation rates of the 5 protein fractions have been described by Sniffen et al. (1992) as follows: PA is assumed to be infinity, fraction $\mathrm{PB} 1$ is 120 to $400 \% / \mathrm{h}$, fraction $\mathrm{PB} 2$ is 3 to $16 \% / \mathrm{h}$, fraction PB3 is 0.06 to $0.55 \% / \mathrm{h}$, and fraction $\mathrm{PC}$ is considered to be undegradable.

\section{Energy Values}

The energy values of total digestible $\mathrm{CP}$, total digestible FA (tdFA), total digestible NFC, total digestible NDF, total digestible nutrients at maintenance $\left(\mathbf{T D N} \mathbf{N}_{\mathbf{1}}\right)$, digestible energy at production level of intake $\left(\mathbf{D E}_{3 \times}\right), \mathrm{ME}$ at production level of intake $\left(\mathbf{M E}_{\mathbf{3} \times}\right)$, and $\mathrm{NE}_{\mathrm{L}}$ at production level of intake $\left(\mathbf{N E}_{\mathbf{L} 3 \times}\right)$ were estimated according to NRC (2001).

\section{Statistical Analysis}

The MIXED procedure of SAS (SAS Institute, 1999) was used to analyze data on chemical profiles, protein subfractions, energy values, and FT/IR spectra. The model used for analysis was

$$
Y_{i j}=\mu+T_{i}+e_{i j},
$$

where $Y_{i j}$ is an observation on the dependent variable $i j, \mu$ is the overall population mean, $T_{i}$ is the fixed effect of heat treatment (moist vs. dry heating), and $e_{i j}$ is the random error associated with the observation ij. The harvest years (2010 and 2011) were used as replications.

The model used for in situ rumen degradation and intestinal digestibility of RUP was

$$
Y_{i j k}=\mu+T_{i}+R_{k}+e_{i j k},
$$

where $Y_{i j k}$ is an observation on the dependent variable $i j, \mu$ is the overall population mean, $T_{i}$ is the fixed effect of heat treatment (moist vs. dry heating), $R_{k}$ is the in situ experimental run with 4 cows as a random effect, and $e_{i j k}$ is the random error associated with the observation $i j k$. The years $(2010,2011)$ were used as replication. When significant $(P<0.05)$ differences were detected, post-hoc analyses were carried out using least significant difference test to compute pairwise differences in the means. Means with different superscript letter groups were obtained with PDMIX 800 SAS macro (Saxton, 1998).

\section{RESULTS AND DISCUSSION}

\section{Heat-Induced Changes in Chemical Profile}

Results on the heat-induced changes in the chemical profile of camelina seeds are shown in Table 1. Compared with the control, dry heating significantly increased the DM content, indicating that dry heating 
decreased the moisture-holding capacity of the camelina seeds. The contents of EE increased $(P<0.05)$ with both dry and moist heat treatments. The increase in ether extractability with heat treatments in the current study is in line with the findings of Doiron et al. (2009) and Samadi and Yu (2011). The increase in EE could be related to physical changes caused by heating, such as the denaturation of the protein matrix, which removes the effect of steric hindrance (Huang, 1992), and to the transformation of the secondary structure of oleosins, which separates oleosins and oil bodies through decreased hydrophobicity (Huang, 1996). Moreover, heating ruptures the delicate membranes of oil bodies, allowing them to coalesce (Ponne et al. 1996). Overall, these heat-induced changes in cellular structures expose the oil bodies to solvents, which causes the high oil extraction.

The contents of $\mathrm{CHO}$ decreased $(P<0.05)$ with both heat treatments; however, no differences were observed between dry and moist heating (Table 1). The NFC content decreased with heating, and the difference compared with raw seeds was significant $(P<0.05)$ for the dry heating. The increase in EE concentration by heating could have attributed to the decrease in $\mathrm{CHO}$ and NFC concentrations, as $\mathrm{CHO}$ was calculated as $100-\mathrm{EE}-\mathrm{CP}$ - ash, and NFC was calculated as $100-(\mathrm{NDF}-\mathrm{NDIP})-\mathrm{EE}-\mathrm{CP}-$ ash, according to NRC (2001). Moreover, the lower NFC content may also be related to the consumption of sugar during heat processing (Maillard reaction). In the present study, no significant changes were detected in the content of NDF with heat treatments. Samadi and Yu (2011) reported a significant increase in NDF content of soybeans, whereas Doiron et al. (2009) reported a significant decrease in the NDF content of Vimy flaxseed with heating. These results demonstrate that different oilseed models react differently to heat processing.

The $\mathrm{CP}$ content was not changed $(P>0.05)$ by heat treatments. Our results are consistent with earlier findings (Mustafa et al., 2003; Doiron et al., 2009; Samadi and $\mathrm{Yu}, 2011$ ). Compared with raw seeds, moist heating markedly decreased the SCP content (52.73 to $20.41 \% \mathrm{CP}$ ). In agreement with our findings, marked decreases in the SCP fractions of flaxseeds (51.88 to 18.82\% CP; Doiron et al., 2009) and soybeans (43.38 to $11.35 \%$ CP; Samadi and Yu, 2011) with moist heating (at $120^{\circ} \mathrm{C}$ for $1 \mathrm{~h}$ ) have been reported. Interestingly, the NPN content was increased $(P<0.05)$ by moist heating. This result was supported by Doiron et al. (2009); however, Mustafa et al. (2003) and (Samadi and $\mathrm{Yu}, 2011$ ) observed a decrease in NPN content with moist heating. This discrepancy may be related to the inherent differences in seed types or to differences in heating duration and NPN methodology (tungstic acid vs. TCA, filter paper pore size, and so on). The content of NDIP increased $(P<0.05)$ from $2.00 \%$ (control) to $9.01 \%$ after moist heating, which is consistent with earlier findings (Doiron et al. 2009; Samadi and Yu, 2011). Dry heating did not $(P>0.05)$ change the SCP, NPN, and NDIP contents.

The chemical profile changes indicated that the susceptibility of camelina seeds to methods of heating was

Table 1. Chemical profiles: raw (control) versus heat treatments of camelina seeds

\begin{tabular}{|c|c|c|c|c|c|c|}
\hline Item & Control & \multicolumn{2}{|c|}{ Heat treatment ${ }^{1}(\mathrm{HT})$} & SEM & $\frac{\text { Contrast }(P \text {-value })}{\text { Control vs. HT }}$ & $P$-value \\
\hline \multicolumn{7}{|l|}{ Basic chemical profile } \\
\hline Ether extract (EE; \% of DM) & $35.52^{\mathrm{c}}$ & $37.99^{\mathrm{a}}$ & $37.07^{\mathrm{b}}$ & 0.205 & $<0.001$ & $<0.001$ \\
\hline Ash (\% of DM) & 3.94 & 3.84 & 3.98 & 0.137 & 0.87 & 0.76 \\
\hline \multicolumn{7}{|l|}{ Carbohydrate/fiber profile (\% of DM) } \\
\hline $\mathrm{ADL}$ & 1.27 & 1.30 & 1.27 & 0.029 & 0.81 & 0.72 \\
\hline $\mathrm{NFC}^{3}$ & $17.56^{\mathrm{a}}$ & $17.00^{\mathrm{ab}}$ & $16.12^{\mathrm{b}}$ & 0.344 & 0.042 & 0.046 \\
\hline \multicolumn{7}{|l|}{ Protein profile } \\
\hline Total CP (\% of DM) & 25.18 & 24.93 & 25.58 & 0.267 & 0.82 & 0.27 \\
\hline Soluble CP (SCP; \% of CP) & $52.73^{\mathrm{a}}$ & $20.41^{\mathrm{b}}$ & $56.46^{\mathrm{a}}$ & 1.570 & $<0.001$ & $<0.001$ \\
\hline $\mathrm{NPN}(\%$ of $\mathrm{CP})$ & $14.64^{\mathrm{b}}$ & $18.22^{\mathrm{a}}$ & $16.58^{\mathrm{ab}}$ & 0.897 & 0.033 & 0.057 \\
\hline
\end{tabular}

\footnotetext{
${ }^{\mathrm{a}-\mathrm{c}}$ Means within a row with different superscript letters differ at the $P<0.05$ level.

${ }^{1} \mathrm{HT}-1=$ autoclave heating at $120^{\circ} \mathrm{C}$ for $60 \mathrm{~min}$; HT-2 = dry heating at $120^{\circ} \mathrm{C}$ for $60 \mathrm{~min}$.

${ }^{2}$ Total carbohydrate $=100-\mathrm{EE}-\mathrm{CP}-$ ash $(\mathrm{NRC}, 2001)$.

${ }^{3} \mathrm{NFC}=100-[\mathrm{NDF}-$ neutral detergent-insoluble protein (NDIP) $]-\mathrm{EE}-\mathrm{CP}-$ ash (NRC, 2001).

${ }^{4} \mathrm{ADIP}=$ acid detergent-insoluble protein.
} 
distinct. Moist heating was more efficient in altering the protein profile of camelina seeds than dry heating.

\section{Heat-Induced Changes in Protein Subfractions}

Results on the heat-induced changes in CNCPS protein subfractions are presented in Table 2. Moist heating decreased $(P<0.05)$ the PB1 fraction and increased the PB2 and PB3 fractions compared with raw seeds. The PB1 (rapidly degradable), fraction markedly decreased from 45.06 to $16.69 \%$ (\% of CP) with a subsequent increase in PB2 (the intermediately degradable) fraction from 45.28 to $70.58 \%$ (\% of CP). These findings are consistent with values from the literature (Doiron et al. 2009; Samadi and Yu, 2011) and suggest that feed protein will be more gradually degraded in the rumen after moist heating. Moreover, a substantial increase in the PB3 fraction (1.13 to $8.02 \%$ of CP) was observed with moist heating. In agreement with our findings, Samadi and $\mathrm{Yu}$ (2011) observed an increase in the PB3 fraction from 0.8 to $12.7 \%$ after $1 \mathrm{~h}$ of moist heating of soybeans. The PB3 fraction is believed to be more slowly degraded in the rumen and a large portion of this fraction escapes degradation in the rumen. In contrast, dry heating did not significantly change the content of the PB1, PB2, and PB3 subfractions compared with raw seeds. Fraction PC is considered to be associated with lignin, tannins, and heat-damaged protein such as the Maillard reaction products that are not digestible in the rumen and not available to animals (Sniffen et al., 1992). Heat treatments did not $(P>0.05)$ change the content of fraction PC. These findings demonstrate that moist heating decreased protein degradability in the rumen but did not overprotect protein from digestion in the small intestine. The changes in CNCPS protein subfractions depend on the method of heat processing (moist vs. dry heating), and moist heating was much more effective in manipulating protein subfractions than dry heating.

\section{Heat-Induced Changes in Energy Content}

The contents of digestible nutrients were estimated according to reported equations of NRC (2001). Data on the estimated truly digestible nutrients and energy values of camelina seeds as affected by dry and moist heating $\left(120^{\circ} \mathrm{C}\right.$ for $\left.1 \mathrm{~h}\right)$ are summarized in Table 3 . Both dry and moist heating significantly $(P<0.05)$ increased the contents of tdFA and $\mathrm{TDN}_{1 \times}$ compared with raw seeds. Samadi and Yu (2011) also observed a numeric increase in the tdFA and $\mathrm{TDN}_{1 \times}$ contents of soybeans with dry and moist heating. Among the heat-treated seeds, tdFA and $\mathrm{TDN}_{1 \times}$ were higher $(P$ $<0.05)$ on moist heating, which is supported by the higher EE content of moist-heated seeds compared with dry-heated seeds.

Table 2. Protein subfraction profiles using the Cornell Net Carbohydrate and Protein System (CNCPS): raw (control) versus heat treatments of camelina seeds

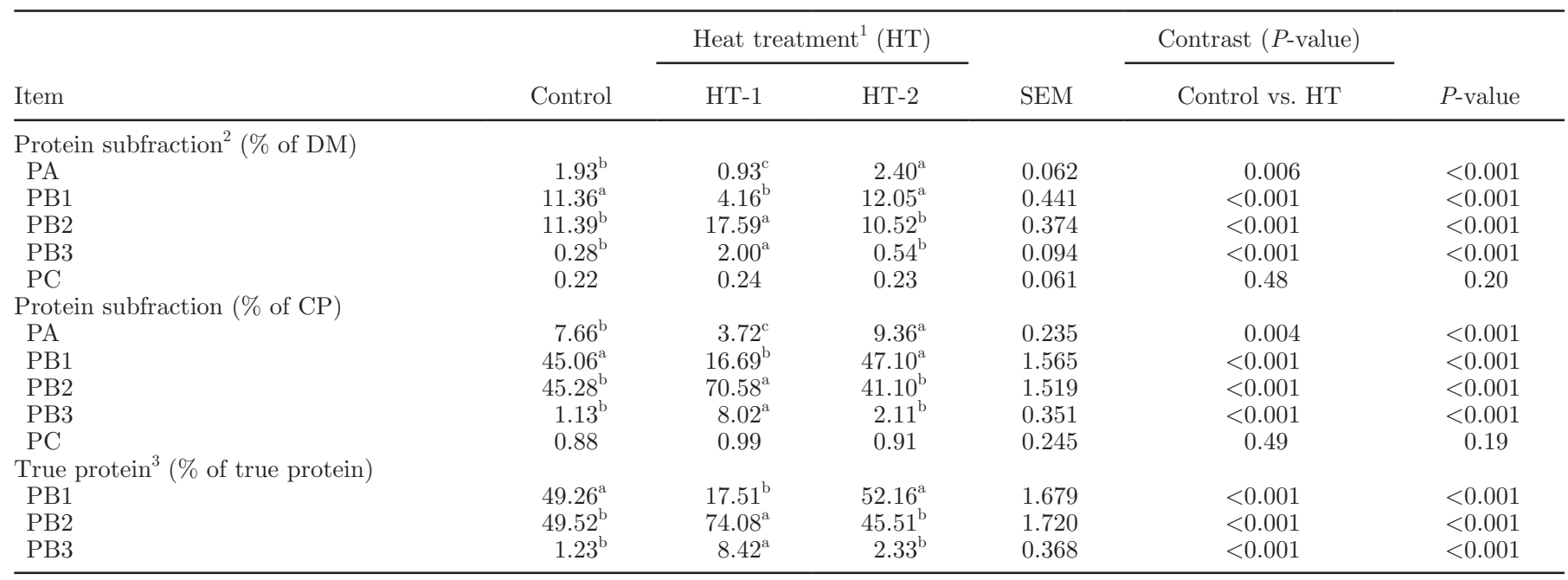

${ }^{\mathrm{a}-\mathrm{c}}$ Means within a row with different superscript letters differ at the $P<0.05$ level.

${ }^{1} \mathrm{HT}-1=$ autoclave heating at $120^{\circ} \mathrm{C}$ for $60 \mathrm{~min}$; HT-2 = dry heating at $120^{\circ} \mathrm{C}$ for $60 \mathrm{~min}$.

${ }^{2} \mathrm{PA}=$ fraction of $\mathrm{CP}$ that is instantaneously solubilized at time zero; $\mathrm{PB} 1=$ fraction of $\mathrm{CP}$ that is soluble in borate-phosphate buffer and precipitated with TCA; PB2 = intermediately degradable fraction and calculated as total CP minus the sum of fractions PA, PB1, PB3, and PC; PB3 = slowly degradable protein fraction and calculated as the difference between the portions of total CP recovered with NDF and ADF; $\mathrm{PC}=$ fraction of $\mathrm{CP}$ recovered with $\mathrm{ADF}$ and considered to be undegradable. It contains protein associated with lignin and tannins and heatdamaged protein such as the Maillard reaction products.

${ }^{3}$ True protein $=\mathrm{PB} 1(\%$ of $\mathrm{CP})+\mathrm{PB} 2(\%$ of $\mathrm{CP})+\mathrm{PB} 3(\%$ of $\mathrm{CP})$. 
Table 3. Digestible nutrients and estimated energy values: raw (control) versus heat treatments of camelina seeds

\begin{tabular}{|c|c|c|c|c|c|c|}
\hline Item & Control & \multicolumn{2}{|c|}{ Heat treatment ${ }^{1}(\mathrm{HT})$} & SEM & $\frac{\text { Contrast ( } P \text {-value) }}{\text { Control vs. HT }}$ & $P$-value \\
\hline \multicolumn{7}{|c|}{ Digestible nutrients (NRC, 2001, summary approach) } \\
\hline Total digestible $\mathrm{CP}(\mathrm{tdCP} ; \%$ of $\mathrm{DM})$ & 25.09 & 24.83 & 25.55 & 0.277 & 0.78 & 0.23 \\
\hline Total digestible FA (tdFA: $\%$ of DM) & $34.52^{\mathrm{c}}$ & $36.99^{\mathrm{a}}$ & $36.07^{\mathrm{b}}$ & 0.205 & $<0.001$ & $<0.001$ \\
\hline Total digestible NDF (tdNDF: $\%$ of DM) & 10.28 & 9.21 & 9.92 & 0.439 & 0.21 & 0.26 \\
\hline $\mathrm{ME}_{3 \times}$-dairy ${ }^{4}$ & $4.80^{\mathrm{b}}$ & $4.95^{\mathrm{a}}$ & $4.90^{\mathrm{a}}$ & 0.016 & $<0.001$ & $<0.001$ \\
\hline $\mathrm{NE}_{\mathrm{L} 3 \times}$-dairy ${ }^{5}$ & 3.41 & 3.53 & 3.43 & 0.035 & 0.13 & 0.079 \\
\hline
\end{tabular}

${ }^{\mathrm{a}-\mathrm{c}}$ Means within a row with different superscript letters differ at the $P<0.05$ level.

${ }^{1} \mathrm{HT}-1=$ autoclave heating at $120^{\circ} \mathrm{C}$ for $60 \mathrm{~min}$; HT-2 = dry heating at $120^{\circ} \mathrm{C}$ for $60 \mathrm{~min}$.

${ }^{2}$ Total digestible nutrients at maintenance.

${ }^{3}$ Digestible energy (DE) at production level of intake.

${ }^{4}$ Metabolizable energy at production level of intake.

${ }^{5}$ Net energy for lactation at production level of intake.

Heat treatments increased $(P<0.05) \mathrm{DE}_{3 \times}$ and $\mathrm{ME}_{3 \times}$ contents for dairy cattle. Research has established that $\mathrm{EE}$ is an important determinant of the energy value of feeds (Theodoridou and Yu, 2013b), and the increase in ether extractability with heating could explain the high energy contents of heat-treated camelina seeds. The contents (Mcal $/ \mathrm{kg}$ of $\mathrm{DM}$ ) of $\mathrm{ME}_{3 \times}$ (4.80) and $\mathrm{NE}_{\mathrm{L} 3 \times}$ (3.41) of camelina (raw) seeds were lower than that the corresponding energy contents of golden flaxseed (Yu, 2005), but higher than that of soybeans (Samadi and $\mathrm{Yu}$ 2011). The reported $\mathrm{ME}_{3 \times}$, and $\mathrm{NE}_{\mathrm{L} 3 \times}$ contents (Mcal $/ \mathrm{kg}$ of DM) of golden flaxseed was 5.20 and 3.75 , and that of soybean was 3.94 and 2.65, respectively, whereas the $\mathrm{DE}_{3 \times}$ content (Mcal $/ \mathrm{kg}$ of $\mathrm{DM}$ ) of camelina seeds (5.05) were lower than golden flaxseed (5.41) and higher than soybeans (4.29).

\section{Changes in Rumen Protein Degradation and Intestinal Digestibility}

Although statistically not significant, a large decrease was observed in the in situ rumen degradation of DM of camelina seeds by moist (72.9 to $61.9 \%)$ and dry (72.9 to $64.3 \%$ ) heating (Table 4 ). Compared with raw seeds, rumen CP degradability was significantly decreased $(P<0.05 ; 75.4$ to $57.9 \%)$ by moist heating. Our results are consistent with the findings of Doiron et al. (2009) and Samadi and Yu (2011), who observed a decrease in rumen CP degradability with moist heating of Vimy flaxseed (62.0 to $49.8 \%$ ) and soybean meal (86.2 to $66.4 \%$ ), respectively. In contrast, no significant difference in CP degradability was observed between raw and dry-heated seeds, for which the values are consistent with values from the literature (Doiron et al.
2009; Samadi and Yu 2011). Moist heating significantly increased (43.90 to $82.95 \%$ ) the intestinal digestibility of RUP compared with raw seeds. In contrast, dry heating did not change the intestinal digestibility of RUP. The decrease in rumen protein degradation and increase in intestinal digestibility of RUP with moist heating can be related to the shift in CNCPS protein subfractions (Samadi and Yu, 2011). The rapidly rumen degradable (PB1) fraction decreased with moist heating, whereas the intermediately degradable (PB2) and slowly degradable (PB3) fractions increased. Moreover, the content of the nondigestible (PC) fraction was not affected by moist heating. Therefore, the high supply of (potentially digestible) RUP to the intestine resulted in high intestinal digestibility of RUP. These results suggest that moist heating, within the scope of the treatment used in this study, can increase dietary RUP without any accompanying decrease in digestibility in the small intestine.

\section{Detection of Heat-Induced Protein Molecular Structure Changes}

Heat processing reduces protein degradation in the rumen and optimizes protein utilization in ruminants by changing protein molecular structures such as denaturation (disorganization of the overall molecular shape of a protein), unfolding or uncoiling of a coiled or pleated structure, or the separation of the protein into its subunits, which may then unfold or uncoil ( $\mathrm{Yu}$, 2007). The heat-induced changes in inherent protein structures, such as the ratios of amide I to amide II area and $\alpha$-helix to $\beta$-sheet affects the rumen and intestinal digestibility of protein by changing protein 
Table 4. In situ rumen degradation and intestinal digestibility: comparison of raw (control) versus heat treatments of camelina seeds

\begin{tabular}{|c|c|c|c|c|c|c|}
\hline Item & Control & \multicolumn{2}{|c|}{ Heat treatment ${ }^{1}(\mathrm{HT})$} & SEM & $\frac{\text { Contrast }(P \text {-value })}{\text { Control vs. HT }}$ & $P$-value \\
\hline \multicolumn{7}{|l|}{ In situ rumen degradability } \\
\hline $\mathrm{CP}(\%)$ & $75.45^{\mathrm{a}}$ & $57.92^{\mathrm{b}}$ & $67.47^{\mathrm{a}}$ & 3.529 & 0.070 & 0.009 \\
\hline Intestinal digestibility of RUP (\%) & $43.90^{\mathrm{b}}$ & $82.95^{\mathrm{a}}$ & $45.50^{\mathrm{b}}$ & 5.447 & 0.019 & $<0.001$ \\
\hline
\end{tabular}

${ }^{\mathrm{a}, \mathrm{b}}$ Means within a row with different superscript letters differ at the $P<0.05$ level.

${ }^{1} \mathrm{HT}-1=$ autoclave heating at $120^{\circ} \mathrm{C}$ for $60 \mathrm{~min}$; HT-2 = dry heating at $120^{\circ} \mathrm{C}$ for $60 \mathrm{~min}$.

solubility (Doiron et al., 2009; Samadi and Yu, 2011), and the access of microbes and proteolytic enzymes to protein molecules in the gastrointestinal tract of dairy cattle (Yu, 2007; Yu and Nuez-Ortín, 2010; Theodoridou and $\mathrm{Yu}, 2013 \mathrm{a})$. Even if feeds contain similar protein contents, their nutritive value may be different if the $\alpha$-helix-to- $\beta$-sheet ratios of their protein secondary structures are different (Samadi and $\mathrm{Yu}, 2011$ ). In the present study, moist heating increased $(P<0.05)$ the ratio of amide I to amide II area, and decreased $(P<$ $0.05) \alpha$-helix height and the ratio of $\alpha$-helix to $\beta$-sheet compared with raw (control) and dry-heated camelina seeds (Table 5). Our results are consistent with the findings of Samadi and Yu (2011). The alteration in the protein structure ratio was probably caused by denaturation of $\alpha$-helices and $\beta$-sheets during the heating process. Moist heating increased the ratios of amide I to amide II area and $\alpha$-helix to $\beta$-sheet (Table 5), which caused a decrease in SCP (52.73 to $20.41 \%$ ) and in situ rumen degradation of CP (75.41 to $57.92 \%)$ and increased (43.90 to $82.95 \%$ ) the intestinal digestibility of RUP. In contrast, dry heating did not change any of the measured spectral characteristics associated with protein structure compared with raw seeds. As a consequence, dry heating did not change SCP, in situ rumen degradation of $\mathrm{CP}$, and intestinal digestibility of RUP.
These findings demonstrate that heat-induced changes in protein chemical profiles, protein subfractions, protein digestive behavior in the rumen, and availability in the small intestine of dairy cows were related to the heat-induced changes in protein molecular structures.

\section{CONCLUSIONS}

Moist heating significantly changed protein chemical profiles, protein subfractions, rumen degradability, intestinal digestibility, and protein molecular structures compared with dry heating. Moist heating markedly decreased CP solubility, protein degradation in the rumen, and increased intestinal digestibility of RUP, and these changes were associated with alterations in protein intrinsic molecular structures, such as the increase in amide I-to-amide II area ratio and decrease in $\alpha$-helixto- $\beta$-sheet ratio. In contrast, dry heating did change CP solubility, rumen degradability, intestinal digestibility, and protein molecular structures compared with raw seeds. Moist heating improved feed-protein utilization in dairy cattle.

\section{ACKNOWLEDGMENTS}

Research projects of the chair group (Peiqiang Yu) have been supported by grants from the Ministry of

Table 5. The structural characteristics of protein revealed by Fourier transform/infrared-attenuated total reflectance (FT/IR-ATR) molecular spectroscopy: raw (control) versus heat treatments of camelina seeds ${ }^{1}$

\begin{tabular}{|c|c|c|c|c|c|c|}
\hline \multirow[b]{2}{*}{ Item } & \multirow[b]{2}{*}{ Control } & \multicolumn{2}{|c|}{ Heat treatment $^{2}(\mathrm{HT})$} & \multirow[b]{2}{*}{ SEM } & \multirow{2}{*}{$\frac{\text { Contrast }(P \text {-value })}{\text { Control vs. HT }}$} & \multirow[b]{2}{*}{$P$-value } \\
\hline & & HT-1 & HT-2 & & & \\
\hline \multicolumn{7}{|c|}{ Protein amide (ca. 1,715-1,482 $\mathrm{cm}^{-1}$ ) } \\
\hline Amide I & 5.118 & 4.969 & 5.268 & 0.2362 & 0.999 & 0.67 \\
\hline Amide II & 2.149 & 1.938 & 2.232 & 0.1224 & 0.67 & 0.23 \\
\hline Amide I:amide II ratio & $2.411^{\mathrm{ab}}$ & $2.576^{\mathrm{a}}$ & $2.376^{\mathrm{b}}$ & 0.0525 & 0.33 & 0.027 \\
\hline \multicolumn{7}{|c|}{ Protein structure of $\alpha$-helix and $\beta$-sheet ${ }^{2}$} \\
\hline$\alpha$-Helix: $\beta$-sheet ratio & $1.093^{\mathrm{a}}$ & $0.964^{\mathrm{b}}$ & $1.140^{\mathrm{a}}$ & 0.0140 & 0.023 & $<0.001$ \\
\hline
\end{tabular}

${ }_{\mathrm{a}, \mathrm{b}}$ Means within a row with different superscript letters differ at the $P<0.05$ level.

${ }^{1}$ Measurements of the protein structural bands are expressed in IR absorbance units.

${ }^{2} \mathrm{HT}-1$ = autoclave heating at $120^{\circ} \mathrm{C}$ for $60 \mathrm{~min}$; HT- 2 = dry heating at $120^{\circ} \mathrm{C}$ for $60 \mathrm{~min}$. 
Agriculture Strategic Research Chair Program, Natural Sciences and Engineering Research Council of Canada (NSERC, Ottawa, ON, Canada), SaskCanola (Saskatoon, SK, Canada), and the Saskatchewan Agricultural Development Fund (ADF, Regina, SK, Canada). Quanhui Peng (PhD student scholarship) was financially supported by the China Scholarship Council (CSC) when he did his PhD projects in Peiqiang Yu's laboratory at the University of Saskatchewan (Saskatoon, SK, Canada). The authors thank Zhiyuan Niu, research assistant, and Colleen Christensen, Director of FII, in the Department of Animal and Poultry Science (University of Saskatchewan) for providing assistance and arranging samples.

\section{REFERENCES}

AOAC (Association of Official Analytical Chemists). 1990. Officials Methods of Analysis. 15th ed. AOAC, Arlington, VA.

Budevska, B. O. 2002. Applications of vibrational spectroscopy in life, pharmaceutical and natural sciences. Pages 3720-3732 in Handbook of Vibrational Spectroscopy. Vol. 5. J. M. Chalmers and P. M. Griffiths, ed. John Wiley and Sons Inc., New York, NY.

Calsamiglia, S., and M. D. Stern. 1995. A three-step in vitro procedure for estimating intestinal digestion of protein in ruminants. J. Anim. Sci. 73:1459-1465.

Cappellozza, B. I., R. F. Cooke, D. W. Bohnert, G. Cherian, and J. A. Carroll. 2012. Effects of camelina meal supplementation on ruminal forage degradability, performance, and physiological responses of beef cattle. J. Anim. Sci. 90:4042-4054.

CCAC (Canadian Council on Animal Care). 1993. Guide to the Care and Use of Experimental Animals. Vol. 1, 2nd ed. CCAC, Ottawa, ON, Canada.

Chouinard, P. Y., V. Girard, and G. J. Brisson. 1997. Performance and profiles of milk fatty acids of cows fed full fat, heat-treated soybeans using various processing methods. J. Dairy Sci. 80:334-342.

Doiron, K., P. Yu, J. J. McKinnon, and D. A. Christensen. 2009. Heatinduced protein structure and subfractions in relation to protein degradation kinetics and intestinal availability in dairy cattle. J. Dairy Sci. 92:3319-3330.

Faldet, M. A., L. D. Satter, and G. A. Broderick. 1992. Determining optimal heat treatment of soybeans by measuring available lysine chemically and biologically with rats to maximize protein utilization by ruminants. J. Nutr. 122:151-160.

Halmemies-Beauchet-Filleau, A., T. Kokkonen, A.-M. Lampi, V. Toivonen, K. J. Shingfield, and A. Vanhatalo. 2011. Effect of plant oils and camelina expeller on milk fatty acid composition in lactating cows fed diets based on red clover silage. J. Dairy Sci. 94:4413-4430.

Henderson, C. 1973. The effects of fatty acids on pure cultures of rumen bacteria. J. Agric. Sci. 81:107-112.

Huang, A. H. C. 1992. Oil bodies and oleosins in seeds. Annu. Rev. Plant Physiol. Plant Mol. Biol. 43:177-200.

Huang, A. H. C. 1996. Oleosins and oil bodies in seeds and other organs. Plant Physiol. 110:1055-1061.

Kirkhus, B., A. R. Lundon, J. E. Haugen, G. Vogt, G. I. A. Borge, and B. I. F. Henriksen. 2013. Effects of environmental factors on edible oil quality of organically grown camelina sativa. J. Agric. Food Chem. 61:3179-3185.

Licitra, G., T. M. Hernandez, and P. J. Van Soest. 1996. Standardization of procedures for nitrogen fractionation of ruminant feeds. Anim. Feed Sci. Technol. 57:347-358.

Moloney, A. P., C. Kennedy, F. Noci, F. J. Monahan, and J. P. Kerry. 2012. Lipid and colour stability of M. longissimus muscle from lambs fed camelina or linseed as oil or seeds. Meat Sci. 92:1-7.
Mustafa, A. F., Y. P. Chouinard, D. R. Ouellet, and H. Soita. 2003 Effects of moist heat treatment on ruminal nutrient degradability of sunflower seed. J. Sci. Food Agric. 83:1059-1064.

Noci, F., F. J. Monahan, and A. P. Moloney. 2011. The fatty acid profile of muscle and adipose tissue of lambs fed camelina or linseed as oil or seeds. Animal 5:134-147.

NRC. 2001. Nutrient Requirements of Dairy Cattle. 7th rev. ed. National Academies Press, Washington, DC

Peiretti, P. G., P. P. Mussa, L. Prola, and G. Meineri. 2007. Use of different levels of false flax (Camelina sativa L.) seed in diets for fattening rabbits. Livest. Sci. 107:192-198.

Ponne, C. T., A. C. Möller, L. M. M. Tijskens, P. V. Bartels, and M. M. T. Meijer. 1996. Influence of microwave and steam heating on lipase activity and microstructure of rapeseed (Brassica napus). J. Agric. Food Chem. 44:2818-2824.

Putnam, D. H., J. T. Budin, and L. A. Field, and W. M. Breene. 1993. Camelina: A promising low-input oilseed. Pages 314-322 in New Crops. J. Janick and J. E. Simon, ed. Wiley Publishing, New York, NY

Roe, M. B., C. J. Sniffen, and L. E. Chase. 1990. Techniques for measuring protein fractions in feedstuffs. Pages 81-85 in Proc. Cornell Nutrition Conf., Ithaca, NY. Cornell University, Ithaca, NY.

Ruegsegger, G. J., and L. H. Schultz. 1985. Response of high producing dairy cows in early lactation to the feeding of heat-treated whole soybeans. J. Dairy Sci. 68:3272-3279.

Salin, S., J. Taponen, K. Elo, I. Simpura, A. Vanhatalo, R. Boston, and T. Kokkonen. 2012. Effects of abomasal infusion of tallow or camelina oil on responses to glucose and insulin in dairy cows during late pregnancy. J. Dairy Sci. 95:3812-3825.

Samadi, and P. Yu. 2011. Dry and moist heating-induced changes in protein molecular structure, protein subfraction, and nutrient profiles in soybeans. J. Dairy Sci. 94:6092-6102.

SAS Institute. 1999. User's Guide: Statistics. 8th ed. SAS Inst. Inc., Cary, NC

Saxton, A. M. 1998. A macro for converting mean separation output to letter groupings in PROC MIXED. Pages 1243-1246 in Proc. 23rd SAS User Group Intl. SAS Institute, Cary, NC.

Sniffen, C. J., J. D. O'Connor, P. J. Van Soest, D. G. Fox, and J. B. Russell. 1992. A net carbohydrate and protein system for evaluating cattle diets: II. Carbohydrate and protein system availability. J. Anim. Sci. 70:3562-3577.

Szumacher-Strabel, M., A. Cieślak, P. Zmora, E. Pers-Kamczyc, S. Bielińska, M. Stanisz, and J. Wójtowski. 2011. Camelina sativa cake improved unsaturated fatty acids in ewe's milk. J. Sci. Food Agric. 91:2031-2037.

Theodoridou, K., and P. Yu. 2013a. Application potential of ATR-FT/ IR molecular spectroscopy in animal nutrition: Revelation of protein molecular structures of canola meal and presscake, as affected by heat-processing methods, in relationship with their protein digestive behavior and utilization for dairy cattle. J. Agric. Food Chem. 61:5449-5458.

Theodoridou, K., and P. Yu. 2013b. Effect of processing conditions on the nutritive value of canola meal and presscake. Comparison of the yellow and brown-seeded canola meal with the brown-seeded canola presscake. J. Sci. Food Agric. 93:1986-1995.

Van Soest, P. J., J. B. Robertson, and B. A. Lewis. 1991. Methods for dietary fiber, neutral detergent fiber, and nonstarch polysaccharides in relation to animal nutrition. J. Dairy Sci. 74:3583-3597.

Wright, C. F., M. A. G. von Keyserlingk, M. L. Swift, L. J. Fisher, J A. Shelford, and N. E. Dinn. 2005. Heat-and lignosulfonate-treated canola meal as a source of ruminal undegradable protein for lactating dairy cows. J. Dairy Sci. 88:238-243.

Yu, P. 2005. Protein secondary structures (a-helix and $\beta$-sheet) at a cellular level and protein fractions in relation to rumen degradation behaviours of protein: A new approach. Br. J. Nutr. 94:655-665.

Yu, P. 2007. Protein molecular structures, protein subfractions, and protein availability affected by heat processing: A review. Am. J. Biochem. Biotech. 3:70-90.

Yu, P., D. A. Christensen, and J. J. McKinnon. 2003. Comparison of the National Research Council-2001 model with the Dutch system 
(DVE/OEB) in the prediction of nutrient supply to dairy cow from forages. J. Dairy Sci. 86:2178-2192.

Yu, P., and W. G. Nuez-Ortín. 2010. Relationship of protein molecular structure to metabolisable proteins in different types of dried distillers grains with solubles: A novel approach. Br. J. Nutr. 104:1429-1437.
Zhang, X., and P. Yu. 2012. Molecular basis of protein structure in combined feeds (hulless barley with bioethanol coproduct of wheat dried distillers grains with solubles) in relation to protein rumen degradation kinetics and intestinal availability in dairy cattle. J. Dairy Sci. 95:3363-3379. 